Arts

et Savoirs

\section{Arts et Savoirs}

15 | 2021

Revisiting Medical Humanism in Renaissance Europe

\title{
The Manuscripts of Galen in the Library of Cardinal Bessarion: A Reappraisal
}

Pour une réévaluation des manuscrits de Galien conservés dans la bibliothèque du cardinal Bessarion

\section{Ciro Giacomelli}

\section{(2) OpenEdition}

\section{Journals}

Electronic version

URL: https://journals.openedition.org/aes/3643

DOI: 10.4000/aes.3643

ISSN: 2258-093X

\section{Publisher}

Laboratoire LISAA

\section{Electronic reference}

Ciro Giacomelli, "The Manuscripts of Galen in the Library of Cardinal Bessarion: A Reappraisal", Arts et Savoirs [Online], 15 | 2021, Online since 25 June 2021, connection on 17 December 2021. URL: http:// journals.openedition.org/aes/3643 ; DOI: https://doi.org/10.4000/aes.3643

This text was automatically generated on 17 December 2021.

Centre de recherche LISAA (Littératures SAvoirs et Arts) 


\title{
The Manuscripts of Galen in the Library of Cardinal Bessarion: A Reappraisal
}

\author{
Pour une réévaluation des manuscrits de Galien conservés dans la bibliothèque \\ du cardinal Bessarion
}

Ciro Giacomelli

1 Galen ranks among the most prolific writers of his time. According to a calculation made by Jean Irigoin, Galen's writing, which occupies 10,000 pages in Kühn's edition, represents an eighth of the surviving Greek literary production from Homer to the second century $\mathrm{AD}^{1}$.

2 Galen engaged extensively with the writing and publication process of his works, often circulating a still provisional text, called proekdosis. Galen was also aware of several forgeries sold and published under his name and, in order to firmly establish the extent of his production, he wrote two short bibliographical texts: On The Order of His Own Books and On His Own Books. While the first explains the order ( $\tau \dot{\alpha} \xi 1 \zeta)$ in which his books should be read, the second systematically lists his works, and provides us with precious information on the circumstances in which he wrote his treatises ${ }^{2}$.

3 It goes without saying that such a vast and dispersed literary production, surviving only partially, had to be arranged in different corpuses during late antiquity and the Middle Ages. At first, Galen's works were transmitted in papyrus rolls, each usually containing one book of a given work. Galen's texts were later copied into the new book format, the codex, comprising more texts and thus forming a physical unity of several works or books of a single treatise. Smaller works were grouped together, often due to their similar content or following the reading list of late-antique medical schools. Longer treatises, on the other hand, were subdivided in units comprising several books (typically five and then ten, forming pentads and decades). Around the ninth century AD, with the introduction of the minuscule script, a single codex could fit whole treatises or sets of related works. Those bulky Byzantine manuscripts and their numerous 
Renaissance copies were the models for the tightly printed five volumes of the Aldine edition of 1525, the first attempt at collecting in a single editorial effort Galen's Greek Opera Omnia .

4 The history of the transmission of Galen works in the original Greek, here only summarily recapitulated, was deeply influenced, among others, by one man: Cardinal Bessarion (c.1403-1472). A Greek émigré, originally from Trebizond, Bessarion became a powerful Catholic cardinal, bridging the gap separating East and West at the twilight of Byzantium. A wise statesman and diplomat, Bessarion was also one of the most remarkable intellectuals of his time, and his immense and highly selective Greek library bears testimony to his tireless and painstaking philological labour ${ }^{4}$.

\section{Bessarion and His Library}

In 1468, Cardinal Bessarion wrote a well-known letter to the Venetian Doge Cristoforo Moro (1390-1471), offering his library to the Serenissima. Venice, according to the Cardinal, was "almost a second Byzantium" in which many Greeks émigrés found secure refuge after the fall of Constantinople in 1453. The letter, which offers precious insights in the history and formation of Bessarion's collection, is a mature reflection on the cultural program the Cardinal carried out in more than five decades: to collect and rescue from destruction and oblivion the fragile heritage of the Greek world ${ }^{5}$.

6 In Bessarion's library, we can clearly see the result of his efforts: almost all literary genres of ancient literature are to be found amongst the shelves of his collection, alongside the classics of the Christian and Byzantine paideia. But the Cardinal, who annotated and corrected a huge number of his manuscripts, did not only limit himself to collecting as many texts and manuscripts as possible, but he also had them copied by his tireless scribes in luxury parchment copies, mostly produced in the last two decades of his life ${ }^{6}$.

7 When, in 1468, the first lot of manuscripts was shipped to Venice, the emptied shelves of Bessarion's library in Rome were already being re-filled with new books: most of them were copied directly from the manuscripts that Bessarion intended to donate, and others were acquired later on. In 1472, Bessarion died while on his way back from an unsuccessful diplomatic mission in France and, according to his will, the remaining part of his library left Rome for Venice, re-joining the manuscripts sent in 1468.

We have two inventories of the library, which offer us a clear picture of the donation in 1468 (inventory A) and 1474 (inventory B). In 1468, Bessarion sent 482 Greek manuscripts and 264 Latin books, while inventory B enumerates 1024 items in total (mixing Greek and Latin).

9 The role of Bessarion's library in the transmission of Greek classics has been stressed more than once. The oldest and best manuscripts of many ancient and Byzantine writers are often to be found in his collection, including Homer (with two, tenthcentury manuscripts, the Veneti A and B), Aristophanes, Euripides, Aristotle, and Plato. It also included the only complete copy of Athenaeus's Deipnosophistae, as well as two important manuscripts of Photius's Bibliotheca - two works that saved from oblivion a huge number of fragments and the names of their authors. The importance of Bessarion's library is not limited to literary texts, however: he also collected technical treatises, including a considerable number of medical texts ${ }^{7}$. 
10 Bessarion had about thirty medical manuscripts in his collection, and some of them played a crucial role in the transmission of the texts they include: this is the case of Marcianus graecus 269, probably the most famous witness of the whole Hippocratic collection, an early tenth-century manuscript from which stemmed a huge number of recentiores ${ }^{8}$. About half of Bessarion's medical shelf was occupied by the works of Galen, undoubtedly the most prolific medical author of antiquity. Excluding codices transmitting only minor excerpts, I have counted fourteen Greek manuscripts still preserved in Venice, at the Marciana: the group is not homogeneous, and a preliminary chronological distinction is to be made. First, I will deal briefly with the older manuscripts, penned between the twelfth and the fourteenth centuries. In this category, only four manuscripts are included - just a fraction of the total. Significantly enough, at least one out of the four was produced in Southern Italy. The remaining ten witnesses were copied in Bessarion's lifetime and nine of them present similar codicological features: they are luxury manuscripts made out of parchment and penned by skilled calligraphers on behalf of the Cardinal'.

11 The importance of the manuscripts owned by Bessarion for the renewed interest in Greek medicine, and particularly in Galen's works, cannot be stressed enough. Véronique Boudon-Millot, in her general overview of the textual transmission of Galen, has dedicated an entire chapter to the fifteenth century - "le siècle de Bessarion", as she styles it - profoundly marked by the Cardinal's library. Indeed, Bessarion's manuscripts were the reason that many Venetian humanists could finally read Galen in the original Greek, sharing their knowledge in nearby Padua, where in the course of the sixteenth century the European medical renaissance started to blossom. As we shall see, it is also thanks to these very manuscripts and their copies that the passage from manuscript to print was made possible. The aim of this article, which is mostly palaeographical and philological in focus, is to offer a closer look at these Venetian witnesses, providing new evidence as to their dating, context of production, and circulation in the Renaissance ${ }^{10}$.

\section{The Older Manuscripts}

12 The oldest manuscript transmitting Galen's work in Bessarion's collection is the Marcianus graecus 288, a large parchment manuscript (305x215) that transmits in 136 densely written leaves the ten books of Galen's De compositione medicamentorum

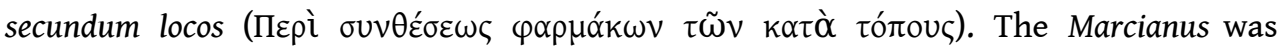
written in angular script by a single scribe, and is an example of the "Reggio-style" writing typical of twelfth-century Siculo-Calabrian book production (centred in Norman-controlled Sicily and Calabria). The hand of this anonymous scribe has been identified in another medical manuscript (folios 1r-95v), the Vaticanus Urbinas Graecus 64, which transmits works of Hippocrates. The same scribe also copied the Vaticani Graeci 1349 and 1391, which were originally united in a single miscellaneous codex containing the romance of Achilles Tatius alongside works of Libanius and Theophylactus Symocattas (the collection of Letters and the Quaestiones naturales). Such interest in medical and rhetorical texts is a traditional feature of Italo-Greek book production and, at the time in which the Marcianus was penned, it represented a sort of cultural and ethnical resistance - an attempt at reconnecting with the Greek and 
Byzantine element, contrasting the inevitable influence of western culture on the Calabrian peninsula and Sicily ${ }^{11}$.

13 A few decades after the Marcianus 288 can be placed the Marcianus Graecus 276, a large paper manuscript (300x230) composed of 271 leaves $^{12}$. This Marcianus is not a unitary codex, but is made up of several different codicological units that were put together in the late thirteenth century. As the existing descriptions of this manuscript are not satisfactory, I would like to draw attention to the distinction of its parts that resulted from an inspection of this complex artefact. The Marcianus 276 is composed of two main codicological units that can be dated to the late twelfth century ${ }^{13}$ : the first one encompasses folios 3-100 (containing a fragment of the final part of book 12 of Galen's De methodo medendi, probably displaced, De sanitate tuenda, De marcore, and the first two books of the De methodo medendi), and the second one contains folios 101-251 (books III to XIV of the De methodo medendi), with a new autonomous quire-signature (first one on f. 108v: $\alpha^{\prime}$ ). These two units were united by a late-thirteenth-century restorer, who added folio 1r-v (now heavily damaged) and consolidated the manuscript by adding new strips of paper where the text was missing on folios 101r, 249r-v, 250r-v, and 251rv. The same restorer, in co-operation with a second hand, then added folios 252-259 (covering the final section of the De methodo medendi). The final part of the manuscript is clearly later and can be placed in the last quarter of the thirteenth century or in the early years of the fourteenth: folios 262-268, an autonomous quaternion, transmit the De atra bile, while folios 269-270 the treatise On Exercise with a Small Ball.

\begin{tabular}{|c|c|}
\hline Scribes & Texts \\
\hline ff. 1r-v: A (late 13 th or early 14 th century): & 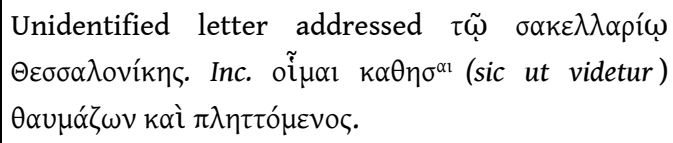 \\
\hline \multicolumn{2}{|l|}{ f. $2 r-v$ blank } \\
\hline ff. 3r-73v: B (late 12th century) & $\begin{array}{l}\text { f. } 3 r \text { : last lines of Galen's De methodo medendi book } \\
12 . \\
\text { ff. } 3 r-68 \text { r: De sanitate tuenda } \\
\text { ff. } 68 \mathrm{r}-73 \mathrm{v} \text { : De marcore }\end{array}$ \\
\hline $\begin{array}{l}\text { f. } 74 \mathrm{r}-\mathrm{v} \text { : C (contemporary with A), this scribe } \\
\text { also wrote the word } \tau \dot{\lambda} \lambda \text { os on } \mathrm{f} .73 \mathrm{v}\end{array}$ & Start of Galen's De methodo medendi \\
\hline ff. $75 r-99 v: B$ & De methodo medendi books 1 and 2 \\
\hline \multicolumn{2}{|l|}{ f. $100 \mathrm{r}-\mathrm{v}$ blank } \\
\hline $\begin{array}{l}\text { ff. } 101 \mathrm{r}-106 \mathrm{r}, 1.6,107 \mathrm{v}-108 \mathrm{v}, 1.6,111 \mathrm{v}, 112 \mathrm{v} \text {, } \\
113 \mathrm{v}-116 \mathrm{r}: \text { D1 (late } 12 \text { th or early } 13 \mathrm{th} \\
\text { century), possibly identical to D2, with a } \\
\text { different ductus }\end{array}$ & De methodo medendi books 3-4. \\
\hline $\begin{array}{l}\text { ff. } 106 \mathrm{r}, 1.6-107 \mathrm{r}, 108 \mathrm{v}, 1.7-111 \mathrm{r}, 112 \mathrm{r}, 113 \mathrm{r}, \\
116 \mathrm{v}-148 \mathrm{v} \text { : D2 }\end{array}$ & De methodo medendi books 3-6 \\
\hline
\end{tabular}




\begin{tabular}{|c|c|}
\hline $\begin{array}{l}\text { ff. } 149 \mathrm{r}-251 \mathrm{v} \text { : E (= D2, wrongly distinguished } \\
\text { by the preceding one by Mioni) }\end{array}$ & 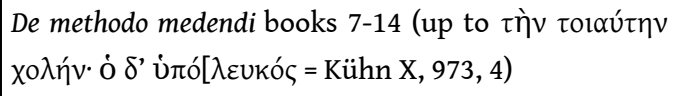 \\
\hline f. 252r-v: C & De methodo medendi, continuation of book 14 \\
\hline ff. 253r-259v: A & 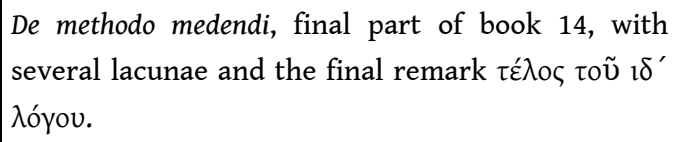 \\
\hline \multicolumn{2}{|l|}{ f. $260 r-v$ blank } \\
\hline ff. $261 \mathrm{r}-268 \mathrm{v}$ : F & 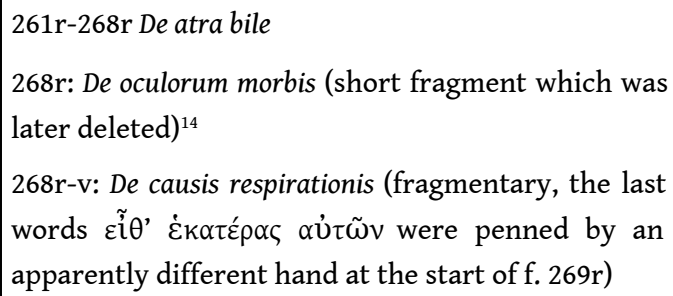 \\
\hline ff. $269 r-270 v: G$ & 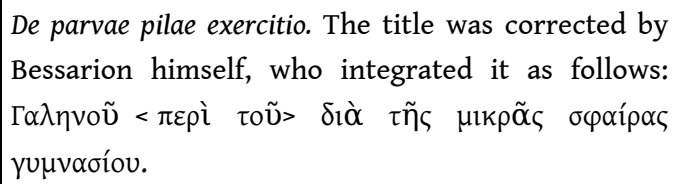 \\
\hline & \\
\hline
\end{tabular}

The manuscript, most probably penned in the East ${ }^{15}$, came to Italy thanks to the learned doctor Pietro D'Abano (1250-1316), who found it in Constantinople. Pietro used this witness for some of his Latin translations of Galen, as recently shown by Antoine Pietrobelli, who also identified scribe $G$ in the Modena manuscript 109, another witness of Galen once belonging to Pietro d'Abano ${ }^{16}$. We do not know how this Marcianus came into possession of Bessarion in the fifteenth century, but he must have acquired it before 1468, when it was listed in the first Venetian inventory ${ }^{17}$.

15 Next comes the Marcianus 278, a smaller manuscript (245x165, 157 folios) penned at the end of the thirteenth century, on oriental paper, by a single scribe who offers a neat example of the so called Fettaugen-Moden script. A few smaller texts written on the last two leaves were penned by a later hand, while folios $1 \mathrm{r}-2 \mathrm{v}$ were added to the manuscript by a fourteenth-century scribe. The Marcianus transmits Galen's commentary on Hippocrates' Aphorisms and the De ratione victus salubri (that is, the third book of the De natura hominis) and, according to a recent survey of the manuscript tradition, it ranks among the independent witnesses of the commentary on the Aphorisms $^{18}$.

16 A small note on the upper margin of folio $3 \mathrm{v}$, which has so far been ignored, can be transcribed as follow:

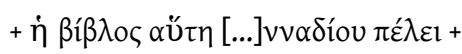

17 This kind of metrical ex libris - a Byzantine hendecasyllable (or sometimes dodecasyllabe) - is quite common and it can be found, in many variants, on several manuscripts ${ }^{19}$. The first letters of what can only be a name in the genitive case are hardly legible because a later hand (Bessarion's?) has cancelled part of the text. Even in 


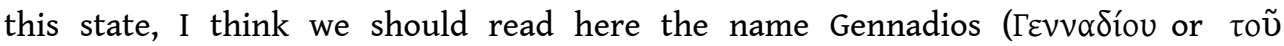
$\Gamma \varepsilon v v \alpha \delta i ́ o v)$. As for the identification of this ancient possessor of the manuscript, I would like to suggest Gennadius Scholarios (1405-1473), whose autographs seems to be consistent with the note on the Marcianus. If this hypothesis proves to be correct, this manuscript should be associated to the Marcianus graecus 264, which bears a monocondylion of Scholarios on folio $246 \mathrm{v}^{20}$.

The last manuscript pertaining to this group, the Marcianus graecus 283, can be dated thanks to its watermarks to the mid fourteenth century. The manuscript has so far been attributed to southern Italy but, even if its script offers some similarities with the Otrantine style, such attribution should be put in question in favour of an eastern origin $^{21}$. The Marcianus 283 plays a relevant role in the textual transmission of Galen since it is the sole witness of his commentary on Hippocrates' Epidemics book 6 . Contrary to a common assumption, this very manuscript was never used as a printer's copy for the Aldine edition of the treatise, which was clearly based on a lost copy of $\mathrm{it}^{22}$.

\section{A Fifteenth-Century Manuscript from Cyprus?}

The Marcianus Graecus 277, containing Galen's commentary on Hippocrates' Aphorisms and a shorter fragment from the Commentary on Hippocrates' De salubri victu, is a puzzling manuscript ${ }^{23}$. It was penned in 1416 by a certain Antonius Mpelchasem, who added a lengthy subscription, full of mistakes, at the end of the text, on folio $255 \mathrm{v}$ :

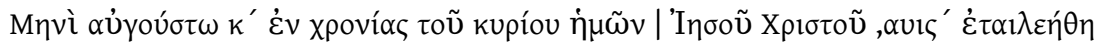

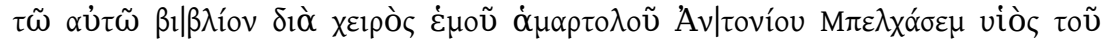

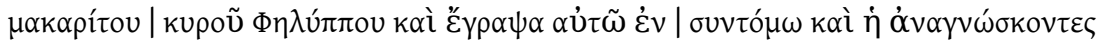

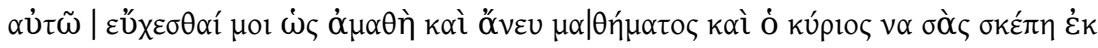

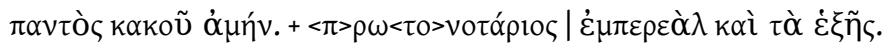

This book was completed on August the 20th AD 1416 by me [litt. by my hand], the sinner Antonios Mpelchasem, the son of sir Philippos, of blessed memory. And I wrote this in a short time and the readers <should> pray for me, as I am ignorant and without education, and the Lord may be with you and protect you from all evil. Amen. The imperial protonotary etc.

Elpidio Mioni, the only scholar to date who has given a palaeographical assessment of the manuscript, claimed the manuscript was copied in Southern Italy, but he did not explain why he came to such a conclusion. The script shows no sign of an Italo-Greek influence but the subscription, and the title of "imperial notary" and the name of the scribe (clearly a transliteration of an Arabic name) betray a provincial origin under Western influence. Following the suggestion of Marie Cronier, I would like to place this manuscript in Cyprus, where a large number of medical manuscripts were copied ${ }^{24}$.

\section{Galen and the Scribes working for Bessarion}

With the Marcianus Graecus 275 we start to deal with the manuscripts copied on Bessarion's behalf and upon his request. Marcianus 275 is a rather large (300x215mm) parchment manuscript written on thirty lines by several scribes under the supervision of the Cretan scholar and copyist Michael Apostolis. The group of scribes who penned the Marcianus alongside Apostolis is the same group we find in two other manuscripts produced for Bessarion's library, namely Marcianus Graecus 405 and Vindobonensis 
Theologici Graeci 75, which are similar in size and with an identical number of lines per page. In at least two of these three manuscripts we find two anonymous hands cooperating with George Tribizias, Michael Lygizos, George Alexandrou, and George Calophrenas - all well-known Cretan scribes ${ }^{25}$.

Marcianus Graecus 275 seems to be a copy of Laurentianus 74, 5: a twelfth-century manuscript copied by the famous scribe Ioannikios and his colleagues ${ }^{26}$. Since these ancient and fragile paper manuscripts were in Italy since at least the end of the twelfth century, and as there is no reason to believe that they were ever sent to Crete, it is reasonable to conclude that they were copied in Italy. The only timeframe that could accommodate the contemporary presence of these scribes in Italy seems to be 1463 , when Apostolis, George Tribizias, Michael Lygizos, and George Alexandrou moved temporarily to the Italian peninsula, under Cardinal Bessarion's protection, in order to escape the impending war between Venice and the Ottoman Empire ${ }^{27}$.

The Cretan scribe Michael Apostolis is the scribe who penned the first codicological unit of Marc. gr. 286 (folios 1-128v), slightly smaller than Marc. gr. 275 but with the same number of lines per page (30). The second part of the manuscript was copied in 1470 by Cosmas Trapezuntius and is clearly independent from the first one ${ }^{28}$. The two sections form together a complete edition of the 11 books of the De simplicium medicamentorum temperamentis ac facultatibus. The manuscript, already in Venice, was annotated in the late fifteenth century by the famous Venetian humanist and patrician Ermolao Barbaro (1454-1493) $)^{29}$, and by one of the scribes working for his household (known as "Anonymus 38 Harlfinger") ${ }^{30}$.

The first half of Marc. gr. 286, as recently shown by Teresa Martínez Manzano, is completed by a manuscript now in Spain (Escurialensis $\Sigma$ II 11), which was separated from the Marcianus at a very early stage. We know that Apostolis copied his text from the Vaticanus Urbinas gr. 67. His work can also be dated quite accurately, thanks to a letter he sent to Bessarion in 1467, where the scribe informs the Cardinal that he is copying the treatise On simple drugs alongside The Doctor and the On the Composition of Drugs according to Places $^{31}$.

Next comes a set of seven parchment manuscripts, Marc. gr. 279-282, 284-285, 287. They all present a similar format (330/360×225/250, with $44-48$ lines per page), allowing them to contain a sizable portion of the still-surviving Galenic works. These luxury manuscripts were produced in Bessarion's later years, when, after the Venetian donation of 1468 , he had new copies made for his soon-to-be-emptied shelves ${ }^{32}$. Most of these manuscripts, as we shall see, are again copies of the set of medical codices copied by Ioannikios and his colleagues.

Marc. gr. 279, annotated by Theodore Gazas, was copied entirely by the Cretan scribe George Calophrenas ${ }^{33}$. It transmits folios 1-202 of the Anatomical Procedures, the commentaries on Hippocrates' De articulis, De fracturis, and De officina medici, which were all derived from Paris. gr. 1849 - a paper manuscript copied by Ioannikios and his colleagues $^{34}$. The second part of the Marcianus (folios 205-269), on the other hand, derives from a manuscript now in Milan, Ambr. B 108 sup., dating from the twelfth or thirteenth century and formerly part of Bessarion's collection ${ }^{35}$.

Marc. gr. 280 was copied in 1470 by John Rhosos, one of the best and most prolific scribes working for Bessarion ${ }^{36}$. The Marcianus transmits the De methodo medendi ad Glauconem and two longer treatises: the De locis affectis and the De compositione 
medicamentorum secundum locos. While the first work still awaits a modern assessment of their manuscript transmission, the last two have recently been the object textual studies by Florian Gärtner, who edited the first two books of the De locis affectis, and Alessia Guardasole. According to Gärtner's assessment of the manuscript tradition, the Marcianus is a copy of Laur. 74, 30, penned in Ioannikios' workshop ${ }^{37}$; on the other hand, in Guardasole's provisional stemma codicum, the Marcianus is a member of the family of Laur. 75, 17, another twelfth-century manuscript copied in Ioannikios' scriptorium ${ }^{38}$. As we shall see, it is highly probable that the Marcianus is an apograph of the Florentine manuscript also for the De compositione medicamentorum secundum locos. Marc. gr. 280 was the source of several renaissance manuscripts produced in Veneto, and in the late fifteenth century, or in the early decades of the sixteenth century, it was read and annotated by the learned Paduan humanist Niccolò Leonico Tomeo and by Giovanni Battista da Lion. The same Lion also copied part of the Vat. Palat. gr. 54 - a descendent of the Marcianus ${ }^{39}$.

Rhosos also copied Marc. gr. 287 (dated 1469) and Marc. gr. 285 (first half, ff. 2r-126v). Marc. gr. 287 is an identical copy of Laur. plut. 74, 18, while the first part of Marc. gr. 285 derives from Marc. gr. 278. The second part of the Marc. gr. 285 (ff. 128r-end), on the other hand, derived from Laur. plut. 74, 25, again coming from Ioannikios' scriptorium, and was transcribed by the Cretan scribe George Alexandrou, who later became professor of Greek in Padua and Rome. Alexandrou copied the entirety of Marc. gr. 281, which transmits several shorter treatises by Galen, most of which were copied from Laur. plut. 75, 5 (ff. $2 \mathrm{r}-75 \mathrm{v}$ of the Marcianus = ff. $166 \mathrm{r}-324 \mathrm{v}$ of the Laurentianus) and 74, 5 (ff. $75 \mathrm{v}-126 \mathrm{v}$ of the Marcianus $=$ ff. $91 \mathrm{r}-122 \mathrm{r}$ and $133 \mathrm{r}-181 \mathrm{v}$ of the Laurentianus), both produced in Ioannikios' scriptorium ${ }^{40}$.

Marc. gr. 282, which was entirely copied by the Cretan scribe George Tribizias, transmits several Galenic texts, and some of its sources are now lost or dispersed ${ }^{41}$. At least one treatise (De inaequali intemperie) was likely copied from Laur. plut. 74, $5^{42}$. In Marc. gr. 282, we again find annotations by Theodore Gazas.

30 The last manuscript of this group is Marc. gr. 284, entirely copied by George Tzangaropoulos, who employed a hieratic script similar to the one of Rhosos', but often freer and more cursive ${ }^{43}$. The red decoration of titles and initials was enriched by green and gold fillings. Here again we find traces of the hand of Theodore Gazas (ff. 59r, 60v, $61 \mathrm{v}, 156 \mathrm{v}, 157 \mathrm{v}$ and several reading notes). Marc. gr. 284 is a copy of Marc. gr. 276 for the De methodo medendi and the Exercises with the small ball ${ }^{44}$.

31 As we have seen, the textual investigation of the Galenic corpus has shown that most of these luxury manuscripts were copied from the ancient and damaged Florentine codices produced in Ioannikios' scriptorium in the twelfth century. This set of papermanuscripts came to Italy in the same century, when it was annotated by Burgundio of Pisa, who also used them for his Latin translations of Galen. Nothing is known of their history in the following century, but they must have re-surfaced somewhere in the course of the fifteenth century, when Bessarion was able to get hold of them and had them copied. A well-known letter of Bessarion to Gazas, which can be dated 1453-1455, sheds some light on the somewhat obscure history of this set of manuscripts ${ }^{45}$ :

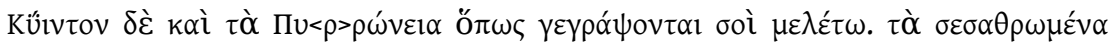

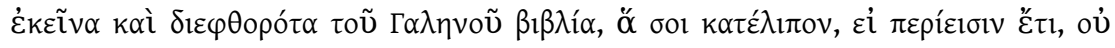

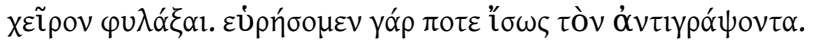

Take care of the transcription of Quintus and of the Pyrrhonian sketches. If they still survive, carefully guard those fragile and damaged books of Galen I have 
entrusted you with. Maybe, sooner or later, we will find somebody capable of copying them. ancient codices produced in Ioannikios' scriptorium and the Galenic manuscripts copied on Bessarion's behalf at the end of the sixth decade of the fifteenth century. Even if we can only speculate on how Bessarion got hold of Ioannikios' copies, the reference to those "fragile and damaged" manuscripts seems to be an allusion to the old paper manuscripts now mostly preserved in Florence, and this mention could offer a precious evidence on their whereabouts in the middle of the fifteenth century ${ }^{46}$.

\section{Some Conclusions: From Bessarion's Library to Europe}

A private library usually only represents a small fraction of the history of the transmission and reception of a text, but Bessarion's collection, as we have seen, is exceptional in several ways. Each manuscript described above documents a step in the transmission of Galen that is itself a chapter of the history of medicine throughout the Middle Ages and the Renaissance; from Byzantium to Cyprus, Southern Italy, and fifteenth-century Rome. Such a diverse corpus, in its most minute details, reflects the wide-ranging and multi-faceted reception of ancient medicine and the richness of Galenism through different ages and cultures. The Latin marginalia by Petro d'Abano in Marc. gr. 276, a manuscript composed of different parts dating from the twelfth and early fourteenth centuries - each documenting a different phase of the history of the text - perfectly epitomise a phenomenon of which the vast complexity cannot be easily rendered in broad strokes.

The Cardinal was able to get hold of ancient manuscripts of Galen dating back to the eleventh or twelfth century, and he also acquired later copies originating from different parts of the Byzantine Empire. This remarkable achievement was not enough, because Bessarion also needed to ensure that the text transmitted by those fragile and rare codices could be read for the centuries to come. The desire to have a complete edition of the Galenic corpus, in a durable and readable set, resulted in the majestic parchment manuscripts produced by Bessarion's best and most enduring scribes in the last years of his lifetime. The efforts Bessarion made for Galen are equal only to the ones he devoted to the transmission of Aristotle, possibly the author he read, studied, and copied the most.

Bessarion set in motion a transformation that slowly but steadily changed Europe. Decades after Bessarion's death, the works of Galen were finally accessible to doctors and philosophers of the Renaissance in the shelves of the Library of San Marco: among the most notable readers were Ermolao Barbaro and Niccolò Leonico Tomeo. They could read, annotate, copy, and translate the whole corpus, which was finally printed in Venice in 1525.

The philological work on the Greek texts of Galen and Aristotle deeply changed the universities of the Italian Renaissance: students and teachers questioned the reliability of the existing Latin translation and, once they got access to the original text, they finally put it under close scrutiny, inevitably cracking the once undisputed authority of the two ancient writers and leading the way to a generation of scholars that gave birth 
to the renaissance of the medical studies at the end of the fifteenth century and continued in the sixteenth century.

\section{NOTES}

1. Jean Irigoin, Tradition et critique des textes grecs, Paris, Les Belles Lettres, 1997, p. 211 (the 10,000 pages do not count the Latin translation that usually occupies half of each page).

2. Véronique Boudon-Millot, Galien, tome I, Introduction Générale, Sur l'ordre de ses propres livres, sur ses propres livres, Que l'excellent médecin est aussi philosophe, Paris, Les Belles Lettres, 2007, p. 3-234.

3. On the dynamics of text-transmission in late antiquity see Luciano Canfora, Conservazione e perdita dei Classici, Padova, Editrice Antenore, 1974, exp. p. 9-23. A general overview of the Galenic tradition and the formation of the different corpora in Boudon Millot, op. cit., n. 2, p. cxIV-CXLIII; Paola Degni, "Textual Transmission of Galen in Byzantium", in Petros Bouras-Vallianatos \& Barbara Zipser (eds), Brill's Companion to the Reception of Galen, Leiden, Brill, 2019, p. 124-139 and Caroline Petit, Simon Swain \& Klaud-Dietrich Fischer (eds), Pseudo-Galenica. The Formation of the Galenic Corpus from Antiquity to the Renaissance, London, The Warburg Institute, 2021. A subdivision in pentads (or at least shorter textual units grouping together books 1-5 and 6-11) is observed by Caroline Petit, «La tradition manuscrite du traité des Simples de Galien. Editio princeps et traduction annotée des chapitres 1 à 3 du livre I ", in Véronique Boudon-Millot, Antonio Garzya, Amneris Roselli (eds), Histoire de la tradition et édition des Médecins Grecs, Napoli, M. D'Auria Editore, 2010, p. 143-165, p. 147. It is clear that such a subdivision should be traced back to a physical separation of the two sets of books in two manuscripts of almost equal size. On the Aldine editio princeps see Nikolaus Mani, “Die griechische Editio princeps des Galenos (1525), ihre Entstehung und ihre Wirkung", Gesnerus, vol. XIII-1,2, 1956, p. 29-52.

4. On Bessarion and his influence see Claudia Märtl, Christian Kaiser, Thomas Rickiln (eds), "Inter graecos latinissimus, inter latinos graecissimus". Bessarion zwischen den Kulturen, Berlin/Boston, Walter de Gruyter, 2013 and S. Mariev (ed.), Bessarion's Treasure. Editing, Translating and Interpreting Bessarion's Literary Heritage, Berlin/Boston, Walter de Gruyter, 2021.

5. The letter can be found in Lotte Labowsky, Bessarion's Library and the Biblioteca Marciana. Six Early Inventories, Roma, Edizioni di Storia e Letteratura, 1979, p. 147-149.

6. On Bessarion's library, see the essays collected by Gianfranco Fiaccadori (ed.), Bessarione e l'Umanesimo, Napoli, Vivarium, 1994.

7. On this point see at least Elpidio Mioni, "Bessarione bibliofilo e filologo", Rivista di Studi Bizantini e Neoellenici, n.s. 5, 1968, p. 61-83. Further evidence on Bessarion's Library will be offered in a forthcoming volume edited by Antonio Rigo \& Niccolò Zorzi, Bessarion's Books. Studies on the Cardinal's manuscripts in Venice and around Europe, Turnhout, Brepols, in press.

8. See Jacques Jouanna, «L'Hippocrate de Venise (Marcianus Gr. 269; coll. 533): nouvelles observations codicologiques et histoire du texte ", Revue des études grecques, vol. CXIII, 2000, p. 193-210.

9. These manuscripts are included in the first volume of the Venetian catalogue (Elpidio Mioni, Codices Graeci Manuscripti Bibliothecae Divi Marci Venetiarum, I, Thesaurus Antiquus, Roma, Istituto Poligrafico e Zecca dello Stato, 1981). I was able to inspect all the Galenic manuscripts described below and in every instance the information offered by the catalogue has been verified and, when necessary, corrected. 
10. Boudon-Millot, op. cit., n. 2, p. CLXXXVIII-CXCIII.

11. On this manuscript see the description offered by Niccolò Zorzi in Codici greci dell'Italia meridionale, a cura di Paul Canart e Santo Lucà, Roma, Retablo, 2000, p.91-92 (n. 33). More recently see also Santo Lucà, "Testi medici e tecnico-scientifici del Mezzogiorno greco", in La produzione scritta tecnica e scientifica nel medioevo: libro e documento tra scuole e professioni. Atti del Convegno internazionale di studio dell'Associazione italiana dei Paleografi e Diplomatisti (Fisciano - Salerno, 28-30 settembre 2009), Spoleto, Centro Italiano di Studi sull'Alto Medioevo, 2012, p. 551-605, here p. 578 and 583 (with previous literature).

12. The manuscript is made of oriental paper of different sorts. The sections which can be attributed to the 12th century are made of Spanish paper while the most recent ones are on paper without watermarks but probably of Italian origin.

13. See already Antoine Pietrobelli, «Les manuscrits grecs de Pietro d'Abano", Quaderni per la storia dell'Università di Padova, n 50, 2017, p. 23-49 and Nicoletta DarlonPalmieri, «Le traité De la bile noire traduit par Pietro d'Abano: manuscrits et éditions imprimées ", Galenos, n 11, 2017, p. 105-119, p. 113, n 40. Nigel G. Wilson, "Aspects of the Transmission of Galen", in Le strade del testo, a cura di Guglielmo Cavallo, Bari, Adriatica, 1987, p. 45-64, p. 57 and n. 51 dates the manuscript to the 12th-13th century, but does not offer any further detail concerning its composition.

14. See Barbara Zipser, "Deleted Text in a Manuscript. Galen On the Eye and the Marc. gr. 276", Galenos, vol. III, 2009, p. 107-112.

15. The manuscript has long been considered of Italo-Greek origin, but this claim seems unfounded. Cf. Guglielmo Cavallo, "La trasmissione scritta della cultura greca antica in Calabria e in Sicilia tra i secoli X-XV", Scrittura e Civiltà, n 4, 1980, p. 157-245, p. 161, n. 8 and 232. See also Anna Maria Ieraci Bio, "La trasmissione della letteratura medica greca nell'Italia meridionale fra X e XV secolo", in Contributi alla cultura greca nell'Italia meridionale, a cura di Antonio Garzya, Napoli, Bibliopolis, 1989, p. 133-257, p. 183.

16. Cf. Antoine Pietrobelli, op. cit., with all the relevant bibliographical references.

17. Lotte Labowsky, op. cit., p. 165, n. 207 "Item eiusdem Galieni de regimine sanitatis et therapeutica, in papyro".

18. See Christina Savino, "Per una nuova edizione del Commento agli Aforismi di Galeno: La tradizione greca", in Sulla tradizione indiretta dei testi medici greci: $i$ commenti. Atti del IV Seminario Internazionale di Siena, Certosa di Pontignano, 3-4 giugno 2011, a cura di Stefania Fortuna, Ivan Garofalo, Alessandro Lami e Amneris Roselli, Pisa-Roma, 2012, p. 29-57, p. 31-32 and 53; Christina Savino, Galeno, Commento agli Aforismi di Ippocrate libro VI, Berlin, Walter de Gruyter, 2020 (CMG V, $12,6)$, p. 22-24.

19. See the many occurrences of similar formulae registered by the Database of Byzantine Book Epigrams (www.dbbe.ugent.be).

20. On Gennadio Scholarios see Marie-Hélène Blanchet, Georges-Gennadios Scholarios (vers 1400-vers 472). Un intellectual orthodoxe face à la disparition de l'Empire byzantin, Paris, Institut Français d'Études Byzantines, 2008. On the Marc. gr. 264 see the description provided by Paolo Eleuteri in I Greci in Occidente. La tradizione filosofica, scientifica e letteraria dalle raccolte della Biblioteca Nazionale Marciana, a cura di Gianfranco Fiaccadori \& Paolo Eleuteri, Venezia, Il Cardo, 1996, nº 13, p. 14 .

21. Cf. Nigel G. Wilson, op. cit., p. 60 and Véronique Boudon-Millot, op. cit., n. 2, p. CLXXXVII. I thank Prof. Santo Lucà (University of Rome "Tor Vergata") for kindly providing me with an expertise on this point.

22. Cf. Véronique Boudon-Millot, "La tradition manuscrite des Médicaments composes selon les genres de Galien (Kühn XIII, 362-1058): nouveaux apports ", Revue des études grecques, $n^{\circ} 131,2018$, p. 451-478, p. 472. The manuscript shows no sign of usage in the printing process. 
23. See Savino, "Per una nuova edizione del Commento agli Aforismi di Galeno: La tradizione greca", op. cit., n 18, p. 35 and Id., Galeno, Commento agli Aforismi di Ippocrate libro VI, op. cit., n. 18, p. 43-44.

24. See Marie Cronier, "Quelques manuscrits médicaux grecs liés à Chypre", in Christian Brockmann, Daniel Deckers, Dieter Harlfinger, Stefano Valente (eds), Griechisch-byzantinische Handschriftenforschung, Berlin/Boston, 2020, p. 131-143, with further bibliography.

25. On this point I shall refer to Ciro Giacomelli, "Medica Patavina. Codici greci di Medicina a Padova, fra Bessarione, Niccolò Leonico Tomeo e Marco Antonio Della Torre", Revue d'histoire des textes, $\mathrm{n}^{\circ} 16,2021, \mathrm{p} .75-113$.

26. Cf. Véronique Boudon-Millot, op. cit., n. 2, p. cXc-CXI (who refers to Mariarosa Formentin, I codici greci di medicina nelle Tre Venezie, Padova, Liviana, 1978, p. 50), but this reconstruction should be backed by a more systematic philological investigation. On Ioannikios and his scriptorium see the overview offered by Paola Degni, "I manoscritti dello 'scriptorium' di Gioannicio", Segno e testo, $\mathrm{n}^{\circ}$ 6, 2008, p. 179-248.

27. See Ciro Giacomelli, op. cit., n. 25.

28. On Michael Apostolis and his "scriptorium" see Rudolf S. Stefec, "Zu Handschriften aus dem Umkreis des Michael Apostoles in Beständen der Österreichischen Nationalbibliothek", Jahrbuch der Österreichischen Byzantinistik, $n^{\circ}$ 63, 2013, p. 221-236. Trapezuntius was one of the most prolific scribes working for Bessarion in the last two decades of his life, on his production see at least David Speranzi, Omero, i cardinali e gli esuli. Copisti greci di un manoscritto di Stoccarda, Mardid, Editorial Dykinson, 2016, n 39, p. 141-142.

29. On Ermolao Barbaro see at least Niccolò Zorzi, "Per la tradizione manoscritta dell'inedito commento all'Etica Nicomachea di Giorgio Pachimere: I. Il Marc. gr. 212 di Bessarione e i suoi apografi. II. Ermolao Barbaro e il commento di Pachimere (con una proekdosis del cap. 18)", NÉ $\alpha$ 'P $\omega \mu \eta \eta, \mathrm{n}^{\circ}$ 12, 2015, p. 245-304.

30. The evidence on this point is offered in Ciro Giacomelli, op. cit., n. 25. On the "Anonymus 38 Harlfinger" and his connection with Ermolao Barbaro, see now Stefano Martinelli Tempesta, "Un nuovo manoscritto della biblioteca di Ermolao Barbaro il giovane: il Mutin. gr. A.K.3.31 (gr. 200) con il commento agli 'Analitici primi' di Giovanni Filopono”, Archivum mentis, n 8, 2019, p. 275-302 (esp. p. 284 and 292-293).

31. See Teresa Martínez Manzano, "Certezas e incógnitas sobre la colleción veneciana de códices griegos de Niccolò Barelli”, Erytheia, n 40, 2019, p. 237-265, p. 246. On the transmission of the work see Caroline Petit, "Les manuscrits grecs du traité des Simples de Galien ", Archives Internationales d'Histoire des Sciences, $\mathrm{n}^{\circ} 70,2020$, p. 76-112 (with previous literature).

32. On this set of Marciani see Jean Irigoin, « Autour des sources manuscrites de l'édition princeps de Galien ", in Storia e ecdotica dei testi medici greci. Atti del II Convegno Internazionale, Paris, 24-26 maggio 1994, a cura di Antonio Garzya, Napoli, M. D’Auria Editore, 1996, p. 207-216 [now reprinted in Jean Irigoin, La tradition des textes grecs. Pour une critique historique, Paris, Les Belles Lettres, 2003, p. 669-681.

33. And not George Tzangaropoulos, as stated by Christian Brockmann, "Textkritische Überlegungen zu Ioannikios als Schreiber von Galen- und Aristotelestexten", in Actes du Vie Colloque International de Paléographie Grecque (Drama, 21-27 septembre 2003), Athêna, Socitété hellénique de reliure, 2008, p.615-632, p.622, n.26. On other medical manuscripts copied by Calophrenas see Marie Cronier, «Comment Dioscoride est-il arrivé en Occident? À propos d'un manuscrit byzantin, de Constantinople à

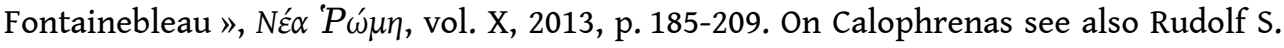
Stefec, "Die Handschriften der Sophistenviten Philostrats", Römische Historische Mitteilungen, vol. LVI, 2014, p. 137-206: 180. The identification of Gazas is also mine, but Luigi Orlandi, "Escerti galenici nella biblioteca di Teodoro Gaza", Studi medievali e 
umanistici, $\mathrm{n}^{\circ} 13,2015$, p. $267-273$, had already noticed that a collection of Galenic excerpts assembled by Gazas seems to derive from manuscripts in Bessarion's possession.

34. See Christian Brockmann, op. cit., p. 621-622.

35. On this point I shall again refer to Ciro Giacomelli, op. cit., n. 25.

36. See Speranzi, op. cit., p. 47-48 with n. 12.

37. F. Gärtner, Galen, Über das Erkennen erkrankter Körperteile I-II, Berlin, Walter de Gruyter 2015, (CMG V, 6,1,1), p. 49-51.

38. See Alessia Guardasole, "Sur la traduction de Niccolò de Reggio du De compositione medicamentorum secundum locos de Galien », Galenos, n 11, 2017, p. 193-207.

39. See Ciro Giacomelli, op. cit., n. 25. On Niccolò Leonico Tomeo cf. Eleonora Gamba, "Un nuovo manoscritto copiato da Niccolò Leonico Tomeo (Par. gr. 1833). Appunti per la ricostruzione della sua biblioteca", Eikasmós, n 25, 2014, p. 329-359. On the little-known humanist Giovanni Battista da Lion I shall refer to Ciro Giacomelli, "Giovanni Battista da Lion (c. 1480-1528) e la sua biblioteca greca", Quaderni per la storia dell'Università di Padova, 49, 2016, p. 35-159. On the medical interests of Tomeo and his circle see Ciro Giacomelli, "Su di un codice greco di Giovanni Zaccaria Attuario nella Biblioteca Civica di Padova (C.M. 644)", Revue d'histoire des textes, $\mathrm{n}^{\circ} 13,2018$, p. 93-127.

40. Cf. Brigitte Mondrain, «Le cardinal Bessarion et la constitution de sa collection de manuscrits grecs - ou comment contribuer à l'intégration du patrimoine littéraire grec et byzantin en Occident ", in Märtl, Kaiser, Ricklin, op. cit., p.187-202, p. 192 and Antoine Pietrobelli, Galien, Commentaire au régime des maladies aiguës d'Hippocrate. Livre I, Paris, Les Belles Lettres, 2019, p. cXCI-CXCIII.

41. A full description of the manuscript is provided by Vasiliki Liakou-Kropp, Georgios Tribizias. Ein griechischer Schreiber kretischer Herkunft im 15. Jh., diss. Hamburg, 2002, p. 274-276.

42. See Elsa Garcia Novo, Galen, On The Anomalous Dyskrasia (De inaequali intemperie), Madrid, Editorial Complutense, 2010, p. 22-23 and 41-42 (as shown by Garcia Novo, there is only one handful of very minor separative error between the Marcianus and the Florentine manuscript).

43. For the attribution see Elpidio Mioni, "Bessarione scriba e alcuni suoi collaboratori" in Miscellanea Marciana di Studi Bessarionei, Padova, Antenore, 1976, p. 263-318, p. 313. On this scribe see now Rudolf S. Stefec, op. cit., $\mathrm{n}^{\circ} 31$, p. 181.

44. See Vito Lorusso, Galeno, Metodo Terapeutico, Libri I-II, Roma, Edizioni di Storia e Letteratura, 2018, p. XLV and Véronique Boudon-Millot Boudon-Millot, "Prolégomènes à l'édition du traité de Galien Sur l'exercice avec la petite balle: du nouveau sur le Laurentianus plut. LXXIV, 3 ", in Véronique Boudon-Millot, Antonio Garzya, Jacques Jouanna, Amneris Roselli (eds), Storia della tradizione e edizione dei medici greci. Atti del VI Colloquio internazionale, Paris, 12-14 aprile 2008, Napoli, D’Auria, 2010, p. 71-87.

45. The letter was published by Ludwig Mohler, Kardinal Bessarion als Theologe, Humanist und Staatsmann. Funde und Forschungen, III. Band, Aus Bessarions Gelehrtenkreis, Paderborn 1942, p. 483-484 ( $\left.\mathrm{n}^{\circ} 34\right)$. A new critical text with an Italian translation was offered by Stefano Martinelli Tempesta, "Trasmissione di testi greci esametrici nella Roma di Niccolò V. Quattro codici di Demetrio Xantopulo e una lettera di Bessarione a Teodoro Gaza", Segno e testo, $\mathrm{n}^{\circ} 13,2015$, p. 271-350, p. 280-282. Martinelli Tempesta was also able to identify the addressee, formerly believed to be Michael Apostolis.

46. See Brigitte Mondrain, art. cit., p. 192, n. 15 and Sebastiano Gentile, David Speranzi, "Antichi cataloghi. Gli inventari dei manoscritti greci della libreria medicea privata", in Paola Degni, Paolo Eleuteri \& Marilena Maniaci (eds), Greek Manuscript Cataloguing. Past, Present and Future, Turnhout, Brepols, 2018, p. 15-38, p. 31-33. 


\section{ABSTRACTS}

This article offers an overview of the manuscripts of Galen preserved in Cardinal Bessarion's (d. 1472) library, which was donated to the Venetian Republic between 1468 and 1474. Following a description of the manuscripts, which aims to correct and integrate the existing studies, the article focuses on a group of seven manuscripts copied in the last years of Bessarion's life by several scribes working for him in Rome. The evidence provided here for the first time enables us to better understand an important stage of Galen's reception in the West, which paved the way to the revolution of medical science in the sixteenth century.

Le présent article offre une vue d'ensemble sur les manuscrits de Galien conservés dans la bibliothèque du cardinal Bessarion ( $m$. 1472), qui fit don de sa riche collection de manuscrits grecs à la République de Venise entre 1468 et sa mort. Après avoir présenté les manuscrits galéniques de Bessarion, tout en corrigeant et intégrant les descriptions jusqu'ici publiées, nous nous attachons à un groupe de sept manuscrits récents, copiés dans les dernières années de la vie de Bessarion par différents scribes travaillant à Rome à son service. Les éléments codicologiques, paléographiques et textuels ici présentés nous permettent de mieux comprendre un jalon important dans la réception de Galien en Occident, ouvrant la voie à la révolution médicale du $\mathrm{XVI} \mathrm{e}^{\mathrm{e}}$ siècle.

\section{INDEX}

Keywords: Galen, Bessarion, Medicine, Manuscripts, Greek, Ioannikios

Mots-clés: Galien, Bessarion, Médecine, Manuscrits, Grec, Ioannikios

\section{AUTHOR \\ CIRO GIACOMELLI}

University of Padova 